https://ejournal.uniska-kediri.ac.id/index.php/PROFICIENCY

\title{
THE EFFECTIVENESS OF USING YOUTUBE AS MEDIA IN TEACHING SPEAKING AT MAN 4 KEDIRI
}

\author{
By: Yunita Mariyana
}

\begin{abstract}
Using YouTube as media is one of the ways to teach speaking. Using YouTube as media help students to be better independent English speaker and makes the students easier in learning English. The main purpose of the study is to examine the effectiveness of using YouTube as media on students' speaking score of the eleventh grade IIS-2. Quantitative was selected as a research approach, whereas the research design used was Quasi Experimental by using posttest-only design. This research used two classes which became experimental and control group. The experimental group was taught speaking using YouTube as media, while the control group was taught using picture as media. To collect the data, post speaking tests in experimental and control group were administered. Data were analyzed by using t-test. The findings indicated that score of the experimental group higher than the control group. Thus, it can be concluded that using YouTube as media in teaching speaking is effective.
\end{abstract}

Key word: teaching speaking, YouTube as media

\section{INTRODUCTION}

One of the skills that must be mastered in the English is speaking. It is because speaking is the easiest and most frequently used. Speaking has played an increasingly important role in second/foreign language settings as a means of communication in daily life. It is supported by Khoironiyah as cited in Sabah (2015:2) arguing that Speaking seems intuitively the most important skill to master. The success is measured in terms of the ability to carry out a conversation in language. Speaking is an interactive process of constructing meaning that involves producing, receiving, and processing information. Speaking is very important because by mastering speaking skills, people can carry out conversations with others, give ideas, and exchange information.

In fact, speaking is a complex skill which involves both intrinsic and extrinsic aspects. The intrinsic problems are related to speech. Speech is fluent and, therefore, students have to learn to group words. Nunan as cited in Moya (2015:12) claims that people consider speaking to be more difficult than other skills mainly because it is a productive and spontaneous ability in which the speaker does not have enough time so as to correct the errors which may be included in a message. In addition, they also have to learn how to hesitate, make a pause, backtrack, correct themselves or use fillers. Last but not least, they have to become 
https://ejournal.uniska-kediri.ac.id/index.php/PROFICIENCY

familiar with all sort of difficult phonological aspects.

In learning speaking skill, the students often find some problems. The problem frequently found is that their native language causes them difficult to use the foreign language. They are afraid if they are making a mistake in one of conversation and lack of confident within themselves. The learners are not confident in using English because of two main reasons, they are: afraid of making mistakes and feeling shy (Souriyavongsa et al, 2013:180). Other reason is because lack of motivation to practice the second language in daily conversation. Moreover, the students' speaking score is enough. Beside the reason above, usually the students feel bored with the media in teaching learning, students need a media that can attract their attention and provide comfort in learning speaking.

There are many ways to solve the problems of media in teaching speaking, one of them is using media technology for teaching. Hatch (2011:36) states that in the classroom, technology has proven to be an aid in student learning. Teaching in the classroom using technology is called E-learning nowdays. Technological advancement provides new opportunities for teachers to apply online resources to traditional classrooms. It makes both learning and teaching interesting and meaningful. If students and the teachers have adequate access to the internet, there is a vast number of audio-visual resources available online that can be used in a multiple ways in English classes.
YouTube is video hosting service site. YouTube allows users to upload, view, rate, share, add to favorites, report, comment on videos, and subscribe to other users. It offers a wide variety of user-generated and corporate media videos. Available content includes video clips, TV show clips, music videos, short and documentary films, audio recordings, movie trailers, live streams, and other content such as video blogging, short original videos, and educational videos.

Learning speaking English by using YouTube is an innovative learning system to be developed although this is not a formal system but gives a nice effect in improving the English language. The students are attempted to teach by using YouTube video. This research is important to conduct in order to help the teacher in solving that problem. With the study, the teachers will know of instructional media in teaching speaking more interesting and effective because the students can directly see and hear how to speak proper English. The teachers does not need to use monotonous like writing on the board method anymore.

Based on the explanation above, it can be seen that YouTube is one of media which is necessary to help the students understanding and learning speaking to improve the speaking score.

The study intends to answer the following questions; 1) How is the eleventh graders' speaking ability in experimental group after being taught by using media YouTube; 2) How is the eleventh graders' speaking ability in control group 
which does not taught by using media YouTube; 3) How is the significant difference of speaking ability between the control and the experimental group; 4) Is using YouTube as media in teaching speaking ability at the eleventh grade of MAN 4 Kediri effective.

\section{RESEARCH METHOD}

The objective of this research was to investigate the effectiveness of using YouTube as media in teaching speaking at the eleventh grade of MAN 4 Kediri. Quantitative was selected as an approach to respond to research questions which require numerical data. Meanwhile, the research design selected was Quasi Experimental by using Posttest-Only Control-Group Design. This research used two classes; they were control group and experimental group.

Both groups were scored to determine the outcome. The scores were gotten from the test administered. The results of the test were used to find out whether the treatment applied in experimental group had an effect or a significant difference from control group or not. To find out the effectiveness of using YouTube as media to improve the students' speaking score, the researcher computed data used the result of the test.

This research was done at MAN 4 Kediri, Badas, Kediri which is located at $\mathrm{Jl}$. Melati No.14, Krecek, Badas, Kediri, East Java. The subjects was at the eleventh grade. In determining the subject of research, it was randomly chosen that the subject or class chosen as the experimental group was XI IIS - 2 .
The class consisted of 39 students. Meanwhile, the control group was XI IIS - 3. The class consisted of 39 students.

Instrument has essential function to collect the data. It was the tool used to get the data related to the research focus. The research instrument in this research was test.

The test was is speaking test. The students will be scored based on four components, they are fluency, accuracy, performance, and comprehension. If all components are good, they will get " 20 ". The lower score is "4" points. The test administered for control and experimental group was the same.

This sub-chapter discusses the procedures to get the data that used in conducting research. It presents; Test and Treatment.

a. Test

According to Arikunto (2006:151) test is series of question or practice and another device which is used to measure skill, intelligence, capability or talent which is belonged to individual or group. Post-test was given after they got teaching speaking by using YouTube as Media. The topic in post-test will about Cause and effect, "Cause and Effect of smoking, or social media, or television".

b. Treatment.

This research typically involved two groups. Those groups were given different treatments. Experimental group (XI IIS-2) was given a new treatment; that was have been taught by using YouTube as media. Meanwhile, control group (XI IIS-3) was taught by using picture as media. 
https://ejournal.uniska-kediri.ac.id/index.php/PROFICIENCY

The purpose of the test was to know the students' speaking ability by giving some instruction. The steps for collecting data were: (1) Teacher will give a test. (2) Teacher will distribute the test to students. (3) Teacher will give instructions before students doing test. (4) Students do preparation for 5 minutes. (5) Students present their presentation. (6) The teacher will give the students' score. (7) The score of students' test was analyzed by using SPSS 22.0 version.

\section{RESEARCH FINDING}

The Students' Speaking score In Experimental Group

The students in experimental group were divided into 13 group (each group consisted of 3 students). They used YouTube as media and in learning speaking. There are some activities done by the students: (1) Watching video about cause and effect, (2) Discussing the content of the video, (3) Summarizing the result of the content of the video (4) Presenting the result of discussion, (5) Asking feedback from the teacher, (6) Doing test in the last meeting for scoring.

The percentage of the students who get 'good' scores is $28 \%$, whereas $72 \%$ students get 'very good' scores. To sum up, the students' speaking achievement in experimental group is in 'very good' category with the mean score 90.51 . Furthermore, the mean score of experimental group is higher than the control groups. From the explanation above, it can be concluded that
YouTube can be used as media in teaching speaking and increase the students' speaking score.

\section{The Students' Speaking Score In Control Group}

The students in control group were divided into 13 groups ( each group consisted of 3 students). They were taught by using picture as media. The activities done in the discussion. There are some activities done by the students: (1) Comparing picture about cause and effect, (2) Discussing the difference between two pictures, (3) Summarizing the result of the pictures (4) Presenting the result of discussion, (5) Asking feedback from the teacher, (6) Doing test in the last meeting for scoring.

The percentage of the students who get 'good' scores is 54\%, whereas $46 \%$ students get 'very good' scores. To sum up, the students' speaking score in control group is in 'good' category with the mean score 82.05. From the explanation above, we know that the students' speaking score in control group is lower than experimental group.

Interpreting the result of Significant Difference between the Students' Speaking score in Control and Experimental Group

After finding the results of both groups, the significant difference between students' speaking score achievement in control and experimental group is calculated. SPSS version 22 is used to analyze the data. 
https://ejournal.uniska-kediri.ac.id/index.php/PROFICIENCY

Table of Statistic Difference between Control and Experimental Group

\begin{tabular}{|c|c|c|c|c|c|}
\multicolumn{7}{c|}{ Group Statistics } \\
\hline \multirow{2}{*}{ SCORE } & GROUP & $\mathrm{N}$ & Mean & Std. Deviation & Std. Error Mean \\
& EXPERIMENTAL & 39 & 90.51 & 8.413 & 1.347 \\
& CONTROL & 39 & 82.05 & 11.569 & 1.853 \\
\hline
\end{tabular}

The table reveals a difference in mean value between the control group $(\mathrm{M}=82.05, \mathrm{SD}=11.569)$ and the experimental group $(\mathrm{M}=90.51$, $\mathrm{SD}=8.413)$. In order to examine whether the experimental group and the control group differed significantly in the test achievement, an independent-samples t-test was conducted using an alpha level of 0.05 . The result is indicated in table below:

\section{Table of Independent Samples T-test Result}

Independent Samples Test

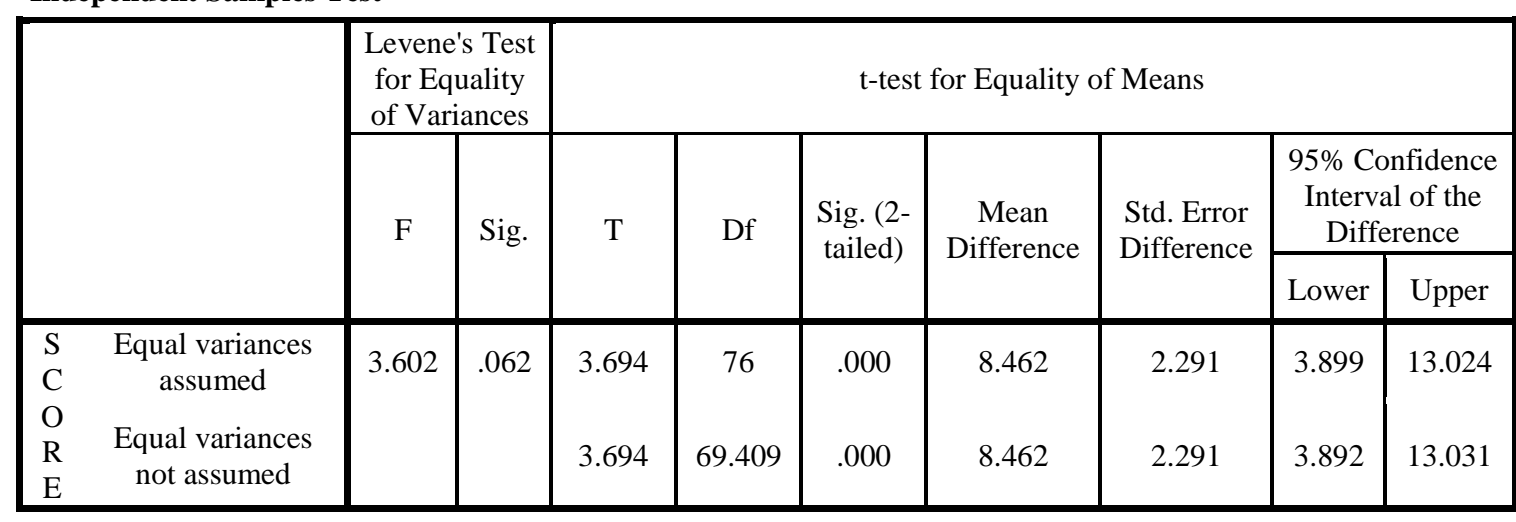

The interpretation of the table above is; there is significant difference between two groups if sig. (2-tailed) value is the same as or is lower than $5 \%$ or 0.05 . From table 4.8 , it can be seen that the experimental group outperformed the control group in speaking score with $\mathrm{t}=3.694$, $\mathrm{df}=76$ and $\mathrm{P}=.000$ and $95 \%$ confidence interval ranging from 3.899 to 1.024 . From the sig. (2-tailed) we can see the $\mathrm{P}$ is lower than $5 \%(0.000<0.05)$. So, it can be conclude that the t-value is significant in 5\% significant level. It means that there is significant difference between control and experimental group.

\section{The Effectiveness of Using YouTube as media to Improve Students' Speaking score \\ After knowing t-test result,} we can be concluded that Alternative Hypothesis (Ha) is accepted. Alternative Hypothesis (Ha) states: using YouTube as media is effective to be used in teaching speaking of cause and effect at the eleventh grade of MAN 4 Kediri. Before testing this hypothesis, t-test is calculated to compare the means between the experimental and control groups. The result reveals that experimental group outperformed the control 
https://ejournal.uniska-kediri.ac.id/index.php/PROFICIENCY

group with significance value $2 \%$ or 0.025 as indicated in table 4.8 .

Significance value (sig. 2tailed) $2 \%$ or 0.025 is lower than alpha level of $5 \%$ or 0.05 . The significant different between both groups is found. Therefore, the Null Hypothesis is rejected in favor of the Alternative Hypothesis. Thus, using YouTube as media is effective to be used in teaching speaking score of descriptive text at the eleventh grade of MAN 4 Kediri.

\section{Conclusion}

After analyzing the data in chapter IV, the conclusions can be drawn are as follows:
1. The students' reading comprehension achievement in experimental group, which is taught by using YouTube as Media, is in a good category with the mean score 90.51 .

2. The students' reading comprehension in control group, which is not taught by YouTube as Media, is in a good category with the mean score 82.05.

3. There is significant difference between the experimental and control group's achievement.

4. YouTube as Media is effective to be used in language teaching specifically in teaching reading.

\section{BIBLIOGRAPHY}

Agazio, J., Buckley, K.M. An untapped resource. Using YouTube in nurse education. Nurse Educator. 2009;34:2328.

Almurashi, W.A. 2016. The Effective Use of YouTube Videos for Teaching English Language in Classrooms as Supplementary Material at Taibah University in Alula. International Journal of English Language and Linguistics Research, 4(3).

Arikunto, S. 2006. Prosedur Penelitian: Suatu Pendekatan Praktik. Jakarta : PT. Rineka Cipta.

Arsyad, A. (2002). Media Pembelajaran. Jakarta: Raja Grafindo Persada

Ary, D. et. (2006). Introduction Research in Education Canada: United State.
Brown, D. H. (2001). Teaching by Principles: An Interactive Approach to Language Pedagogy. White Plains: Pearson Education Company.

Brown, D., (2004). Language Assessment: Principles and Classroom Practice. San Fransisco State University: Longman

Brown, D., (2007). Teaching by principles: An Intermediate Approach to Language Pedagogy. New York: Longman

Daryanto. 2010. Media Pembelajaran. Yogyakarta: Gava Media

Fahs, C. 2008. How to Do Everything with YouTube. New York: McGraw-Hill Osborne Media. 
https://ejournal.uniska-kediri.ac.id/index.php/PROFICIENCY

Grzeszczyk, K. B. 2016. Using Multimedia in the English Language Classroom. Journal of World Scientific News. EISSN 2392-2192

Harmer, J. (2007). How to Teach English. England Longman

Hatch, K. E. 2011. Determining the Effects of Technology on Children. Honors Program at the University of Rhode Island. University of Rhode Island.

Hornby. (1995). Oxford Advanced Learners Dictionary. Oxford: Oxford University Pers.

John W. C. 2008. Educational Research Planning, Conducting, and Evaluating Quantitative and Qualitative Research. New Jersey: Pearson Education, Inc.

Manalu, M. E. R., \& Arifin, T. M. 2013. Improving Students' Speaking Achievement in Oral Descriptive Text By Using Video Transform. Journal of English Language Teaching and Learning of FBS UNIMED, 2(3).

Mayer, R. E. 2002. Multimedia learning. New York: Cambridge University Press.

Murray, C.B. 2014. Measuring Nonverbal Bias trough Body Language Response to Stereotypes. Journal of Nonverbal Behaviour, 38(2)
Nurhasanah. 2017. Buku Guru Bahasa Inggris SMA/MA/SMK/MAK Kelas XI. Jakarta. Kementrian Pendidikan dan Kebudayaan.

Sahlin, D. 2011. YouTube for Dummies. Indianapolis: Wiley Publishing.

Sara, C. W. 2002. Cambridge Language Assessment Series: Assessing writing. Cambridge: Cambridge University Press.

Souriyavongsa, et al 2013. Factors Causes Students Low English Language Learning: A Case Study in the National University of Laos. International Journal of English Language Education, 1(1)

The Top 200 Tools for Learning 2017 List .2017. 'The Top 200 Tools for Learning 2017 List'. Centre for Learning \& Performance Technologies. November $\quad 8, \quad 2017$ <http://www.c4lpt.co.uk/recom mended/2017.html/>. Accessed on 21:02 $1^{\text {st }}$ of December 2017.

Vaughan, T. 2008. Multimedia: Making It Work ( $7^{\text {th }} E d$ ). New Delhi: Mac-Graw Hill

Zanatta, J. A. 2017. Understanding YouTube Culture and How It Affects Today's Media. Journal. Dominican University of California.

Rudolph, T. 2009. YouTube in Music Education. Hal Leonard 